\title{
Effect of climate and insemination technique on reproductive performance of gilts and sows in a subtropical zone of Mexico
}

\author{
Miguel Mellado ${ }^{\mathrm{a}}$, Leticia Gaytán ${ }^{\mathrm{b}}$, Ulises Macías-Cruz ${ }^{\mathrm{c}}$, Leonel Avendaño ${ }^{\mathrm{c}}$, Cesar Meza-Herrera $^{\mathrm{d}}$,

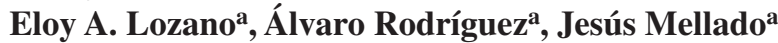

\begin{abstract}
The objective of this study was to analyse the reproductive performance of hybrid (Yorkshire $\mathrm{x}$ Landrace) gilts/ sows in relation to temperature-humidity index (THI) at artificial insemination (AI), season of AI, occurrence of estrus $>8 \mathrm{~d}$ postweaning, repeated estrus, insemination technique (cervical, CAI or post-cervical, PCAI) and parity. Data included 8851 reproductive records (1771 for gilts and 7080 for sows) from a pig farm in a sub-tropical zone (THI ranged from 72.9 in January to 81.8 in June). A decrease in pregnancy rate $(\mathrm{PR}, 89.8$ vs $93.0 \% ; P<0.01)$ and a tendency to decline farrowing rate $(\mathrm{FR}, 87.9$ vs $90.3 \% ; P=0.07)$ following AI during high THI ( $>82)$, compared to $\mathrm{AI}$ at $<74 \mathrm{THI}$ were observed. The spring and summer season were associated with decreased $(P<0.01)$ PR compared with fall and winter $(90.0 \%$ vs $93.0 \%)$. Likewise, FR decreased in spring and summer compared to fall and winter $(88.5 \%$ vs. $90.9 \%)$. FR was higher $(P<0.01)$ in non-repeat breeders compared with that of repeat-breeders $(90.3 \%$ vs $76.2 \%)$. Litter size increased $(P<0.01)$ from $10.8 \pm 3.2$ to $11.1 \pm 3.1$ pigs when the interval from weaning to estrus was $>8 \mathrm{~d}$. The insemination technique did not affect PR and FR but the litter size decreased $(P<0.05)$ from $11.3 \pm 3.0$ to $11.1 \pm 2.9$ pigs when PCAI was used compared to CAI. This study reaffirms the negative effects of the hot season on reproductive performance of gilts/sows, although thermal stress at AI did not cause foetal losses. Also, there is no advantage in using the PCAI as compared to the CAI in gilts/sows with high numbers of sperm cells per AI.

Key words: sows, seasonal infertility, litter size, stillborn piglets, temperature-humidity index.
\end{abstract}

\section{INTRODUCTION}

Reproductive failure interferes with the steady production of pigs, which results in a suboptimal amount of pigs for the market (Holtkamp et al 2013). An important cause of low fertility is high summer ambient temperature which can reduce farrowing rate (FR; 6 to $9 \%$ reduction in the proportion of sows conceiving and maintaining pregnancy in sows weaned in the hot season) (Gourdine et al 2006, Janse van Rensburg and Spencer 2014) and overall reproductive efficiency, both in temperate (Tummaruk et al $2000^{\mathrm{b}}$, Bloemhof et al 2008) and tropical (Tummaruk et al 2004, Suriyasomboon et al 2006) environments.

Additionally, summer heat stress is associated with up to 4 days increase in weaning-to-estrus intervals (Almond and Bilkei 2005, Bertoldo et al 2012), alteration of the reproductive endocrine system, especially the control of luteal and follicular function (Bertoldo et al 2009, Nteeba et al 2015), $15 \%$ reduction in in vitro fertilised embryo developmental potential (Isom et al 2007), a 45\% increase in the incidence of irregular inter-estrus interval (Mazzoni et al 2014), and a reduction of about one piglet per litter

Accepted: 03.10.2017.

aAutonomous Agrarian University Antonio Narro, Department of Animal Nutrition, Saltillo, Mexico.

${ }^{\mathrm{b}}$ Autonomous Agrarian University Antonio Narro, Department of Veterinary Science, Torreon, Mexico.

${ }^{\mathrm{c}}$ Autonomous University of Baja California, Institute of Agriculture Science, Mexicali, Mexico.

${ }^{\mathrm{d} A u t o n o m o u s ~ U n i v e r s i t y ~ o f ~ C h a p i n g o, ~ R e g i o n a l ~ U n i t ~ o f ~ A r i d ~ Z o n e s, ~}$ Bermejillo, Mexico.

Corresponding author: L Gaytán; Torreon, 27059, Mexico; zukygay_7@ hotmail.com
(Prunier et al 1997, Zhao et al 2011, Lopes et al 2014). Moreover, piglets born to sows that experienced heat stress during pregnancy makes them more prone to an altered metabolism resulting in animals with less skeletal muscle (Johnson et al 2015) and weaning weights (Muns et al 2016).

Despite chronic seasonal infertility and compromised sow reproductive performance during and immediately following the warm annual seasons, the biological reasons responsible for impaired fecundity are poorly understood. It has been difficult to determine a specific cause for this phenomenon because many different factors are involved, including photoperiod, heat stress, ambient humidity, phenotype, and management (Auvigne et al 2010).

The use of artificial insemination (AI) in commercial swine operations has skyrocketed in the past decades. One important tool to optimise the use of boars in insemination programs is post-cervical artificial insemination (PCAI), which allows insemination with a reduced number of sperm cells (Fontana et al 2014). This technique has increased fertility from $66 \%$ to $87 \%$ at a lower semen dose compared with cervical artificial insemination (CAI) (Watson and Behan 2002).

Some limited research has been carried out in climate zones $\leq 20^{\circ} \mathrm{N}$ on the relationship between farrowing rate and outdoor temperature, and it is not quite clear if photoperiod or summer heat stress has the prominent role in increased infertility during the hottest period of the year. Also, there is not much information on field fertility outcomes when using the PCAI with "refrigerated" semen in gilts and sows. The aim of this study was to investigate the effect of some factors affecting sow reproductive performance, including season, temperature-humidity index (THI), parity, repeat 
breeding, prolonged weaning-to-first-service interval and insemination technique in a subtropical zone at $20^{\circ} \mathrm{N}$.

\section{MATERIAL AND METHODS}

\section{ANIMALS AND SITE LOCATION}

The study was performed on a single 5500-sow farm located in central west Mexico, from July 2015 to June 2016. The pig farm was located at $20^{\circ} 24^{\prime} 49^{\prime \prime}$ latitude North $102^{\circ} 0$ ' 18 " longitude West, at an altitude of 1765 m. Mean annual temperature in the study site is $20.7^{\circ} \mathrm{C}$ with a maximum of $35^{\circ} \mathrm{C}$ and minimum of $7^{\circ} \mathrm{C}$. The mean annual precipitation is $670 \mathrm{~mm}$. THI ranged from 72.9 in January to 81.8 in June.

Reproductive records of 1771 gilts (females that have not reproduced; 128 to $142 \mathrm{~kg}$ ) and 7080 sows (females that have reproduced; 210 to $248 \mathrm{~kg}$ ) were used.

The sows included in the analyses were born and farrowed within the same herd. The average parity of sows in the study was $3.7 \pm 2.3$, with a range from parity 1 through parity 10 with an average lactation length of $19.2 \pm 2.4$ days. Records from parity numbers above seven were excluded from the statistical analysis.

Sows were commercial line hybrids (Yorkshire $\mathrm{x}$ Landrace). Gilts and sows were kept in an open-house system with a similar feeding and management. Gilts and non-lactating sows received 2.2 to $3.5 \mathrm{~kg} / \mathrm{d}$ of feed with $14 \%$ crude protein and 3,200 to $3,500 \mathrm{kcal} / \mathrm{kg}$ metabolizable energy (ME; two feeding times; 07:00 and 13:00). Nursing sows received 5 to $6 \mathrm{~kg} / \mathrm{d}$ of feed with $17 \%$ to $18 \%$ crude protein and 4,060 kcal/kg ME.

After weaning sows were fed twice daily $(4.0 \mathrm{~kg} / \mathrm{d})$ with a standard corn-soybean diet ( $14 \% \mathrm{CP}, 0.65 \%$ lysine and $3,217 \mathrm{kcal} / \mathrm{kg} \mathrm{ME}$ ). From insemination until $30 \mathrm{~d}$ of pregnancy, the sows were fed $2.4 \mathrm{~kg} /$ day. Between 31 to $90 \mathrm{~d}$ of gestation, they received 1.6 to $2.4 \mathrm{~kg}$ per day; from 90 to $109 \mathrm{~d}$, they were offered 3.0 to $4.0 \mathrm{~kg} /$ day. From $110 \mathrm{~d}$ of gestation until farrowing, sows received $2.0 \mathrm{~kg} /$ day. These feeding guidelines were according to the NRC (2012).

\section{SEMEN COLLECTION AND PROCESSING}

Fresh semen was sourced from a single, 50-boar stud located in a commercial herd near the pig farm, with pure Yorkshire and Landrace boars. The sperm-rich fraction of ejaculates was collected twice a week, by the same operator, from boars aged between one and 3 years, by the gloved-hand method. The semen was directed through a pre-warmed $\left(37^{\circ} \mathrm{C}\right)$ insulated semen collection cup (Minitube, Verona, WI, USA) with a filter to discard the gel fraction. Sperm motility evaluation was performed subjectively under a light microscope at $400 \mathrm{x}$ magnification. Only ejaculates with $\geq 70 \%$ motility were used for AI. Sperm morphology was evaluated in stained smears and only ejaculates with a maximum of $20 \%$ morphological alterations were further processed. Semen was diluted in Beltsville thawing solution (BTS; Minitub®, Tiefenbach, Germany) and doses were prepared with $3 \times 10^{9}$ sperm cells in a total volume of $90 \mathrm{ml}$. The tubes containing semen were stored at $17^{\circ} \mathrm{C}$ until use for AI (24-48 h post-collection). The refrigerated semen was warmed in a water bath at $35^{\circ} \mathrm{C}$ for $15 \mathrm{~min}$ before being used.

\section{ARTIFICIAL INSEMINATION}

Gilts were inseminated at their second observed estrus, at an average of $235 \pm 23$ days of age. On the day of weaning, sows were separated from their litters and moved to a breeding facility. Estrus detection was performed twice daily at 09:00 and 16:00 h, starting the third day after weaning. Sows were in direct contact with a mature boar and the back-pressure test was applied (Hemsworth and Barnett, 1990). Sows that "locked" to boar stimuli and remained quiet to the back-pressure test were inseminated using either the CAI or the PCAI method, in the absence of a boar in front of the sows.

For the PCAI, an intrauterine insemination device (Deep goldenpig $^{\mathrm{TM}}$ catheter, IMV Technologies, L'Aigle, France) was inserted into the cervix. The inner tube extended 200 $\mathrm{mm}$ beyond the tip of the outer catheter lying in the uterine body. Then, extended fresh semen $\left(3 \times 10^{9}\right.$ motile sperm/ dose, $90 \mathrm{ml}$ ) at 12, 24, and $36 \mathrm{~h}$ after the onset of estrus was infused. For the PCAI a disposable foam tip catheter (Minitube of America, Verona, WI) was used.

\section{MANAGEMENT, PREGNANCY DETECTION AND REPRODUCTIVE DATA}

The inseminated sows and gilts were exposed once daily to "teaser" boars from day 18 through 35 after estrus onset. Gestation was confirmed by trans-abdominal ultrasonography (BantamII, EI Medical Imaging, Loveland, CO, USA) at $28 \mathrm{~d}$ post-AI. Non pregnant animals and those returning to estrus twice on consecutive AI were culled from the herd. Gilts/sows were moved to the farrowing pen at 3-5 d before their expected farrowing. Pregnant animals were monitored until farrowing for abortions, and at farrowing, the number of live pigs per litter, the number of stillborn pigs per litter and the number of mummified pigs per litter were recorded.

\section{METEOROLOGICAL DATA}

The climatic data (maximum, minimum, average ambient temperatures and humidity) for the duration of the study were obtained from a meteorological station located $4 \mathrm{~km}$ away from the pig farm. The THI was calculated using the following formula (Thom, 1959):

$$
\mathrm{THI}=(0.8 \times \mathrm{AT}+(\mathrm{RH} / 100) \times(\mathrm{AT}-14.4))+46.4,
$$


where AT is the maximum ambient temperature (registered with a mercury thermometer under full shade; ${ }^{\circ} \mathrm{C}$ ) and $\mathrm{RH}$ is the relative humidity.

\section{STATISTICAL ANALYSES}

Statistical analyses for binomial data were conducted with the GLIMMIX procedure of SAS (SAS Inst. Inc., Cary, NC, USA), with a binomial distribution and a logit link function. Gilts and sows constituted the experimental units with a model that included THI at AI, season of AI, the occurrence of a repeated estrus, extended weaning-tofirst estrus, insemination method (CAI or PCAI), parity (gilts and sows) and first-order interactions. The interaction AI $x$ category was not tested because there were only two observations for gilts.

The THI was classified as being $<74,74-78,78-82$ and $>82$. Seasons were defined as follows: winter (JanuaryMarch); spring (April-June); summer (July-September); autumn (October-December). The occurrence of estrus $>8 \mathrm{~d}$ post-weaning was categorised as yes or no; the occurrence of repeated estrus was classed as yes or no. Treatment means were separated using the probability of a statistical difference (PDIFF option of SAS).
The number of piglets born alive per litter, the number of stillborn pigs per litter and the number of mummified pigs per litter were analysed using the MIXED procedure of SAS, with the means compared by the Tukey test (means/ Tukey option of SAS). A non-linear regression (PROC Nonlin procedure of SAS) was used to describe the association between THI at AI and PR and month of AI and FR. The CORR procedure of SAS was used to assess the correlation between total pigs born and number of mummies per litter and total pigs born and stillborn piglets. Statistical differences were considered at $P<0.05$ and tendencies at $P=0.07$.

\section{RESULTS}

Mean PR as a function of THI the day of AI is shown in table 1. For THI below 78-82 units the pregnancy rate of sows was greater $(P<0.01)$ than sows experiencing severe heat stress at $\mathrm{AI}(\mathrm{THI}>82)$. The highest $\mathrm{PR}$ was observed at THI $<67$ units (values predominant in winter months), then PR remained about the same between 72 and 84 , but at a THI $>84$ a drastic drop in PR was observed (figure 1). FR was consistently higher in all three THI classes for AI at mild climatic conditions.

Table 1. Pregnancy rate, farrowing rates and abortion rate of gilts and sows serviced in different seasons and at different THI indexes, inseminated at different weaning-to-service intervals and with one or more services, and using the cervical or post-cervical insemination techniques.

\begin{tabular}{|c|c|c|c|}
\hline Variables & $\begin{array}{c}\text { Pregnancy rate } \\
(\%)\end{array}$ & Farrowing rate $(\%)$ & $\begin{array}{l}\text { Abortion rate } \\
(\%)\end{array}$ \\
\hline THI at $\mathrm{AI}^{\mathrm{A}, \mathrm{B}}$ & $P=0.009$ & $P=0.07$ & $P=0.001$ \\
\hline$>82$ & $1322 / 1472(89.8)^{\mathrm{b}}$ & $1294 / 1472(87.9)^{\mathrm{b}}$ & $28 / 1322(2.1)^{\mathrm{ab}}$ \\
\hline $78-82$ & $2401 / 2626(91.4)^{\mathrm{ab}}$ & $2371 / 2626(90.3)^{\mathrm{a}}$ & $30 / 2401(1.3)^{\mathrm{b}}$ \\
\hline $74-78$ & $2509 / 2734(91.8)^{\mathrm{a}}$ & $2460 / 2734(90.0)^{\mathrm{a}}$ & $49 / 2509(2.0)^{\mathrm{b}}$ \\
\hline$<74$ & $1878 / 2019(93.0)^{\mathrm{a}}$ & $1823 / 2019(90.3)^{\mathrm{a}}$ & $55 / 1878(2.9)^{\mathrm{a}}$ \\
\hline Season of AI & $P<0.0001$ & $P<0.0006$ & $P<0.001$ \\
\hline Spring & $2019 / 2230(90.5)^{b}$ & $1987 / 2230(89.1)^{\mathrm{bc}}$ & $32 / 2230(1.4)^{\mathrm{a}}$ \\
\hline Summer & $1568 / 1755(89.3)^{\mathrm{b}}$ & $1540 / 1755(87.8)^{\mathrm{c}}$ & $30 / 1755(1.7)^{\mathrm{a}}$ \\
\hline Fall & $2276 / 2448(93.0)^{\mathrm{a}}$ & $2208 / 2448(90.2)^{\mathrm{ab}}$ & $68 / 2448(2.8)^{\mathrm{b}}$ \\
\hline Winter & $2247 / 2418(92.9)^{\mathrm{a}}$ & $2213 / 2418(91.5)^{\mathrm{a}}$ & $34 / 2418(1.4)^{\mathrm{a}}$ \\
\hline Estrus $>8 \mathrm{~d}$ post-wean. & $P>0.10$ & $P>0.10$ & $P>0.10$ \\
\hline Yes & $1022 / 1128(90.6)$ & 1006/1128 (89.2) & $17 / 1128(1.5)$ \\
\hline No & $5450 / 5952(91.6)$ & $5342 / 5952(89.8)$ & $109 / 5952(1.8)$ \\
\hline Repeated estrus & $P<0.0001$ & $P<0.0001$ & $P>0.10$ \\
\hline Yes & $239 / 307(77.9)^{\mathrm{a}}$ & $234 / 307(76.2)^{\mathrm{a}}$ & $6 / 307(2.0)^{\mathrm{a}}$ \\
\hline No & $7871 / 8544(92.1)^{\mathrm{b}}$ & $7714 / 8544 /(90.3)^{\mathrm{b}}$ & $158 / 8544(1.9)^{\mathrm{a}}$ \\
\hline Insemination technique & $P>0.10$ & $P>0.10$ & $P>0.10$ \\
\hline Cervical & $1640 / 1773(92.5)$ & $1602 / 1773(90.4)$ & $38 / 1773(2.2)$ \\
\hline Post-cervical & 6470/7078 (91.4) & 6346/7078 (89.7) & $126 / 7078(1.8)$ \\
\hline Category & $P>0.10$ & $P>0.10$ & $P>0.10$ \\
\hline Gilts & $1638 / 1771(92.5)$ & $1600 / 1771(90.3)$ & $38 / 1773$ (2.2) \\
\hline Sows & $6472 / 7080(91.4)$ & $6348 / 7080(89.7)$ & $126 / 7080(1.8)$ \\
\hline
\end{tabular}

${ }^{\mathrm{A}}$ Interaction THI at artificial insemination $\mathrm{x}$ category for pregnancy rate $P<0.01$.

${ }^{\mathrm{B}}$ Interaction THI at artificial insemination $\mathrm{x}$ category for farrowing rate $P<0.01$.

${ }^{a b c}$ Within columns, means with different superscript letters differ $(P<0.01)$ or there is a tendency to differ $(P=0.07)$. 


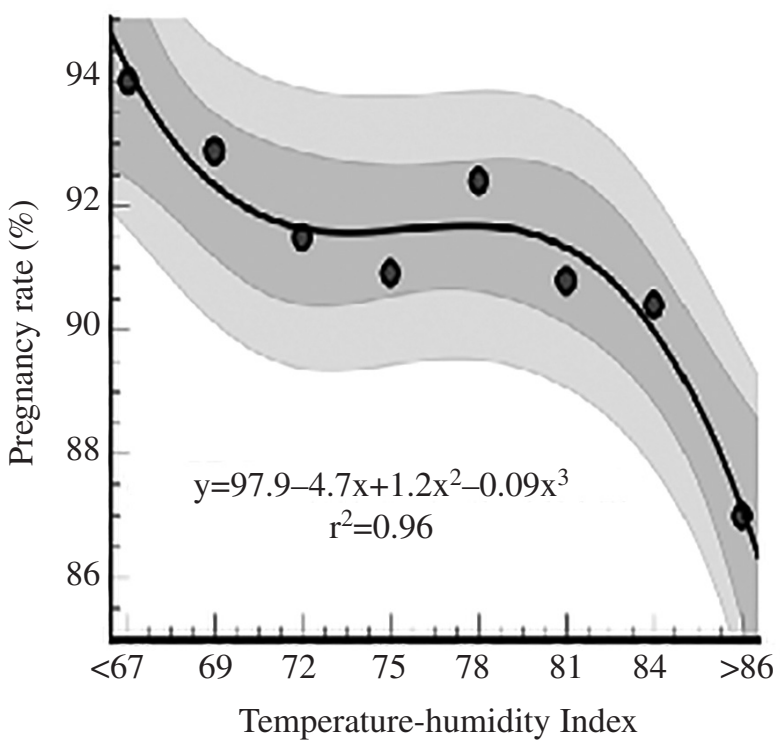

Figure 1. The mean pregnancy rate for different temperaturehumidity indexes in a commercial pig farm (Yorkshire $\mathrm{x}$ Landrace gilts/sows) in a subtropical zone $\left(20^{\circ} \mathrm{N} ; \mathrm{n}=8851\right.$ farrowings $)$. Darker bands are $95 \%$ confidence intervals for predicted values. Lighter bands are $95 \%$ confidence intervals for observations.

Sows inseminated with a THI $>82$ units presented a FR two percentage points lower than sows inseminated during cooler weather conditions. There was a THI $\mathrm{x}$ category interaction $(P<0.01)$ for PR $(88.7$ and 90.1 for gilts and sows, respectively for THI > 82 ) and FR ( 85.8 and $88.4 \%$ for gilts and sows, respectively for THI $>82$ ), gilts being more negatively affected by THI than sows. The highest abortion rate (AR) was observed with the lowest THI at AI (table 1).

Both PR and FR were higher $(P<0.01)$ in sows and gilts inseminated in the spring and winter months as compared with $\mathrm{AI}$ in summer months (figure 2). There was a season of AI x category interaction $(P<0.01)$, sows being more negatively affected by season than gilts for PR (92.5 and $88.7 \%$ for gilts and sows in summer) and FR (92.5 and $88.7 \%$, for gilts and sows in summer, respectively). AR was similar for sows inseminated in spring summer and winter, with the highest $(P<0.01) \mathrm{AR}$ in the fall. AI in sows whose estrus occurred $>8 \mathrm{~d}$ post-weaning did not affect PR, FR or AR. Sows and gilts that were AI more than once presented lower $(P<0.01) \mathrm{PR}$ and FR than animals pregnant at the first insemination. Neither insemination technique (CAI vs PCAI) nor parity affected $(P>0.05)$ PR, FR or AR (table 1).

Out of 8110 gilts and sows that got pregnant in the study, $239(3 \%)$ required more than one AI to get pregnant. There was a significant influence of climate on the occurrence of repeat breeding sows. In animals inseminated during severe climatic conditions (THI $>82$ ) the occurrence of repeat breeding increased 2.2 percentage points $(P<0.01)$

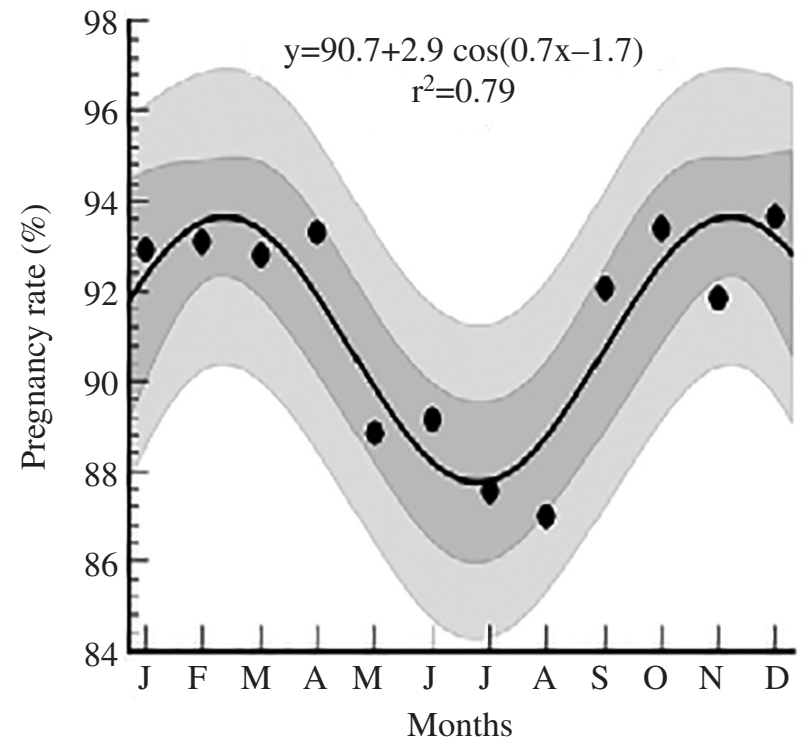

Figure 2. The mean pregnancy rate by breeding month in a commercial pig farm (Yorkshire $\mathrm{x}$ Landrace gilts/sows) in a subtropical zone $\left(20^{\circ} \mathrm{N} ; \mathrm{n}=8851\right.$ farrowings $)$. Darker bands are $95 \%$ confidence intervals for predicted values. Lighter bands are 95\% confidence intervals for observations.

compared with animals inseminated with mild temperatures (THI <74; table 2). The highest percentage of repeat breedings occurred in summer $(P<0.01)$ and the lowest in winter. Repeated AIs were 4 times higher in sows than in gilts. Likewise, the percentage of repeat breeding was much higher $(P<0.01)$ in animals inseminated using the PCAI than the CAI.

The percentage of animals presenting a weaning-tofirst-service interval greater than $8 \mathrm{~d}$ was highest $(P<0.01)$ in animals inseminated with a THI $>82$ and lowest in animals inseminated with a THI between 74 and 78 units. Percentage of gilts/sows with prolonged weaning-to-firstservice interval was highest in winter and lowest in summer $(P<0.01)$.

There was no difference in litter size between gilts/ sows inseminated during mild or warm weather (table 3 ). The lowest $(P<0.01)$ number of dead pigs per litter was observed in animals inseminated with THI $<74$ units, compared to animals inseminated with THI 74-78.

However, dead pigs and mummified fetuses per litter did not differ between animals inseminated during cool or hot climate. Breeding gilts/sows in summer resulted in lower $(P<0.01)$ litter size compared with animals inseminated in other seasons. The number of dead piglets at birth was higher $(P<0.01)$ when animals were inseminated in winter compared to other seasons. Mummies were more numerous $(P<0.01)$ at birth in summer and winter than other seasons. There was a season of AI $x$ category interaction for the occurrence of mummified pigs at birth (1.2 and $0.8 \%$ for gilts and sows in summer, respectively; $P<0.05)$. 
Table 2. The effect of various temperature-humidity indexes at insemination and season of breeding on the occurrence of repeat breeding and estrus longer than 8 days post-weaning.

\begin{tabular}{lcc}
\hline Variables & Repeat breeding $(\%)$ & $\begin{array}{c}\text { Weaning to service interval }> \\
8 \mathrm{~d}(\%)\end{array}$ \\
\hline THI at AI & $P=0.001$ & $P=0.001$ \\
$>82$ & $71 / 1472(4.8)^{\mathrm{b}}$ & $228 / 1198(19.0)^{\mathrm{a}}$ \\
$78-82$ & $105 / 2626(4.0)^{\mathrm{b}}$ & $347 / 2144(16.2)^{\mathrm{b}}$ \\
$74-78$ & $78 / 2734(2.9)^{\mathrm{a}}$ & $234 / 1951(12.0)^{\mathrm{c}}$ \\
$<74$ & $53 / 2019(2.6)^{\mathrm{a}}$ & $319 / 1787(16.3)^{\mathrm{b}}$ \\
Season of AI & $P<0.0001$ & $P<0.0001$ \\
Spring & $75 / 2230(3.4)^{\mathrm{a}}$ & $239 / 1761(13.6)^{\mathrm{a}}$ \\
Summer & $102 / 1755(5.8)^{\mathrm{b}}$ & $364 / 1474(24.7)^{\mathrm{b}}$ \\
Fall & $83 / 2448(3.4)^{\mathrm{a}}$ & $417 / 2044(20.4)^{\mathrm{c}}$ \\
Winter & $47 / 2418(1.9)^{\mathrm{c}}$ & $108 / 1801(6.0)^{\mathrm{d}}$ \\
Category & $P<0.01$ & - \\
Gilts & $15 / 1771(0.9)^{\mathrm{a}}$ & - \\
Sows & $292 / 7080(4.1)^{\mathrm{b}}$ & - \\
Insemination technique & $P<0.01$ & - \\
Cervical & $14 / 1773(0.8)^{\mathrm{a}}$ & - \\
Post-cervical & $293 / 7078(4.1)^{\mathrm{b}}$ & \\
\hline
\end{tabular}

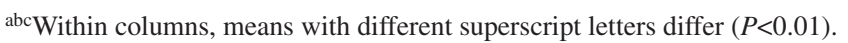

Table 3. Litter size (live pigs), number of stillborn pigs per litter and number of mummified pigs per litter of gilts and sows serviced in different seasons and at different THI indexes, inseminated at different weaning-to-service intervals, with one or more services, and using the cervical or post-cervical insemination techniques.

\begin{tabular}{|c|c|c|c|c|}
\hline Variable & $\mathrm{n}$ & $\begin{array}{l}\text { Number of } \\
\text { live pigs } \\
\text { per litter }\end{array}$ & $\begin{array}{c}\text { Number of } \\
\text { stillborn pigs per litter }\end{array}$ & $\begin{array}{l}\text { Number of mummified } \\
\text { pigs per litter }\end{array}$ \\
\hline THI at artificial insemination (AI) & & $P=0.49$ & $P<0.01$ & $P=0.08$ \\
\hline$>82$ & 1322 & $10.9 \pm 3.3$ & $0.91 \pm 1.0^{\mathrm{ab}}$ & $0.69 \pm 1.1$ \\
\hline $78-82$ & 2401 & $11.0 \pm 3.2$ & $0.92 \pm 1.1^{\mathrm{ab}}$ & $0.75 \pm 1.3$ \\
\hline $74-78$ & 2509 & $10.9 \pm 3.2$ & $0.98 \pm 1.2^{\mathrm{a}}$ & $0.79 \pm 1.3$ \\
\hline$<74$ & 1878 & $10.9 \pm 3.4$ & $0.88 \pm 1.0^{\mathrm{b}}$ & $0.79 \pm 1.1$ \\
\hline Season of artificial insemination ${ }^{\mathrm{A}}$ & & $P<0.002$ & $P<0.0001$ & $P<0.0001$ \\
\hline Spring & 2019 & $11.1 \pm 3.2^{\mathrm{a}}$ & $0.98 \pm 1.1^{\mathrm{a}}$ & $0.62 \pm 1.1^{\mathrm{a}}$ \\
\hline Summer & 1568 & $10.7 \pm 3.3^{\mathrm{b}}$ & $0.87 \pm 1.0^{\mathrm{b}}$ & $0.87 \pm 1.3^{\mathrm{b}}$ \\
\hline Fall & 2276 & $10.9 \pm 3.4^{\mathrm{a}}$ & $0.81 \pm 0.9^{\mathrm{b}}$ & $0.71 \pm 1.1^{\mathrm{c}}$ \\
\hline Winter & 2247 & $11.0 \pm 3.2^{\mathrm{a}}$ & $1.1 \pm 1.1^{\mathrm{c}}$ & $0.87 \pm 1.3^{\mathrm{b}}$ \\
\hline Estrus $>8$ days post-weaning & & $P<0.006$ & $P=0.07$ & $P=0.38$ \\
\hline Yes & 1022 & $11.1 \pm 3.1^{\mathrm{a}}$ & $0.89 \pm 0.9$ & $0.76 \pm 1.2$ \\
\hline No & 5450 & $10.8 \pm 3.2^{\mathrm{b}}$ & $0.96 \pm 1.1$ & $0.72 \pm 1.1$ \\
\hline Repeated estrus & & $P=0.10$ & $P=0.80$ & $P=0.66$ \\
\hline Yes & 234 & $11.4 \pm 3.1$ & $0.97 \pm 1.4$ & $0.74 \pm 1.2$ \\
\hline No & 7714 & $11.1 \pm 2.9$ & $0.95 \pm 1.0$ & $0.78 \pm 1.2$ \\
\hline Insemination technique & & $P=0.03$ & $P=0.75$ & $P>0.0001$ \\
\hline Cervical & 1602 & $11.3 \pm 3.0^{\mathrm{a}}$ & $0.96 \pm 1.1$ & $0.97 \pm 1.5^{\mathrm{a}}$ \\
\hline Post-cervical & 6346 & $11.1 \pm 2.9^{b}$ & $0.95 \pm 1.1$ & $0.73 \pm 1.2^{\mathrm{b}}$ \\
\hline Category & & $P=0.04$ & $P=0.75$ & $P<0.0001$ \\
\hline Gilts & 1593 & $11.3 \pm 2 .{ }^{9} \mathrm{a}$ & $0.95 \pm 1.1$ & $0.97 \pm 1.5^{\mathrm{a}}$ \\
\hline Sows & 6327 & $11.1 \pm 2.9^{b}$ & $0.95 \pm 1.1$ & $0.73 \pm 1.2^{\mathrm{b}}$ \\
\hline
\end{tabular}

Values are means \pm standard deviations

${ }^{\mathrm{A}}$ Interaction season of AI x category for occurrence of mummified pigs $(P<0.05)$

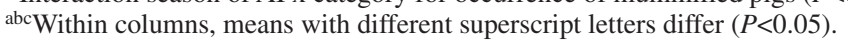


Litter size at birth was higher $(P<0.01)$ in sows whose first estrus was over $8 \mathrm{~d}$ post- weaning. The occurrence of estrus $>8 \mathrm{~d}$ post-weaning produced negligible differences in dead pigs at birth and number of mummified piglets compared with sows whose first heat after weaning was $<8 \mathrm{~d}$. The average number of piglets born alive per litter was greater in gilts/sows inseminated with the CI method as compared with the PCAI. Litters resulting from repeat breeding were similar than that of litters resulting from non-repeat breeding. Litters from gilts were larger $(P<0.001)$ than litters from sows (about 0.2 piglets per litter; table 3 ).

\section{DISCUSSION}

The average farrowing rate across all months in this study was $89.8 \%$ which is above the $85 \%$ value considered as an appropriate target under commercial conditions in temperate climates (Gadea et al 2004, Young et al 2010). High ambient temperatures in the present study decreased both PR and FR. This is in line with others reports where high ambient temperature, leading to heat stress, have caused 5 to 10 percentage point reduction in FR in temperate areas, such as countries in northern Europe and the USA (Tummaruk et al 2004ª, Bloemhof et al 2008, Iida and Koketsu 2016) in crossbred sows. Wider differences have been observed in tropical climate with Large White sows where FR have decreased 13 to 23 percentage points (Egbunike and Steinbac 1980, Gourdine et al 2006) with matings in summer months as compared to winter months.

The reduction of PR by heat stress appears to be dependent on the severity and duration of the heat stress regimen. Under climatic chamber conditions, for example, temperatures up to $30^{\circ} \mathrm{C}$ did not affect FR (Williams et al 2013), but in northern Europe, matings between July and October results in about 8 percentage points FR reduction than matings in winter months (Peltoniemi et al 1999, Tummaruk et al $2000^{\mathrm{a}}$ ). The reduction of reproductive performance of gilts/sows under high ambient temperature is due, among other things, to the hampering of the successful implantation and impairment of embryo development. Wettemann et al (1988), for instance, observed fragmenting conceptuses in heat-stressed gilts, whereas all conceptuses from the control gilts were normal. Likewise, the wet weight of conceptuses of the heat-stressed gilts averaged $233 \mathrm{mg}$ compared to $366 \mathrm{mg}$ for conceptus from control gilts. Isom et al (2007) also observed 45.6\% apoptotic response in IVF embryos subjected to heat stress compared to $26.7 \%$ in non-stressed embryos. It has been documented that $\mathrm{LH}$ secretion is subject to stress effects, mediated by cortisol (Love et al 1993) and this is critical for the successful establishment and maintenance of pregnancy. However, this negative effect of heat stress on embryo survival appears to be dependent on the duration and severity of heat stress prevailing in early gestation. Temperatures up to $34^{\circ} \mathrm{C}$ from d 3 to d 30 or d 24 after mating, have not reduced embryo survival (Liao and Veum 1994). But Tompkins et al (1967) observed that exposure of sows to $35^{\circ} \mathrm{C}$ for $24 \mathrm{~h}$ on day 1 of gestation resulted in $13.2 \%$ fewer viable embryos per 100 corpora lutea than non-stressed sows, which indicates that the beginning of pregnancy is a sensitive stage to thermal stress.

The insemination technique did not affect PR and FR. It has been reported that farrowing rate with intra-uterine AI decreased drastically compared to cervical AI ( $75 \%$ vs 94\%; with $0.5 \times 10^{9}$ spermatozoa per dose) in primiparous $\mathrm{F}_{1}$ (same genotype) sows (Serret et al 2005). However, Sbardella et al (2014) did not find any differences in the farrowing rate $(91.5 \%$ vs. $89.1 \%)$ for PCAI $\left(1.5 \times 10^{9}\right.$ sperm cells in $45 \mathrm{ml} ; 2.4$ doses per sow $)$ and CAI $\left(3 \times 10^{9}\right.$ sperm cells in $90 \mathrm{ml} ; 2.5$ doses per sow) for Landrace $\mathrm{x}$ Large white primiparous sows, although this trial was carried out under controlled conditions, and results may change under commercial conditions. Thus, PCAI seems to be beneficial only when a reduced number of sperm cells are used (sex-sorted semen) or reduced the lifespan of sperm cells (frozen-thawed semen). From the practical standpoint, however, PCAI is more advantageous because time and labor are reduced because no boar is required during PCAI and normally CAI takes much longer than PCAI.

High THI index the day of AI resulted in greater percentage of gilts/sows with repeat breeding and weaning-to-service interval $>8 \mathrm{~d}$, which is in line with other researchers who have observed 2 to $4 \mathrm{~d}$ longer weaning-to-service intervals and higher proportions of returns to service at high ambient temperatures ( 7.8 vs $3.1 \%$ for sows experiencing temperatures $>35^{\circ} \mathrm{C}$ or $<30^{\circ} \mathrm{C}$ ) in hybrid sows (Almond and Bilkei 2005, Iida and Koketsu 2013). Kornegay and Thomas (1983) observed that gilts and sows (undescribed breed) maintained in cooled buildings after weaning returned to estrus five days sooner than those housed in naturally ventilated buildings. Ambient temperature and photoperiod influence weaning-to-service intervals through direct effects on the hypothalamus-hypophyseal-ovarian axis (Hurtgen and Leman 1980, Britt et al 1983). Feed intake reduction might play a role in the delayed return-to-estrus after weaning under high ambient temperature (Muns et al 2016).

The use of CAI method reduced the incidence of returns to estrus post-breeding compared with PCAI. PCAI likely increases the percentage of repeat breeding because there are many more management steps with this technique that increase the likelihood of errors occurring when compared with CAI. In the present study, THI during the day of AI did not affect litter size. This lack of effect is not clear because the number of live pigs per litter was reduced in summer. This is consistent with various reports in European countries where summer temperatures have decreased litter size in $\mathrm{F}_{1}$ or $\mathrm{F}_{2}$ genetic lines of Landrace x Large White sows (Peters and Pitt 2003, Almond and Bilkei 2005). Also in tropical climates, Suriyasomboon 
et al (2006) and Tummaruk et al (2004) observed that high temperature and humidity at previous weaning/mating or at farrowing had negative effects on litter size in purebred Swedish Landrace and Swedish Yorkshire as well as in Landrace x Yorkshire sows. High ambient temperatures in summer possibly affected ovulation rate, uterine capacity, and embryonic and foetal survival, all components of the litter size trait (Wu et al 2006, Distl 2007).

In the present study it was found that litter size increased by about 0.3 pigs when weaning to service interval was greater than $8 \mathrm{~d}$ as compared with intervals $<8 \mathrm{~d}$. This is contrary to results obtained in a number of previous studies (Dewey et al 1995, Le Cozler et al 1997, Tummaruk et al 2000 ) where a negative effect of weaning-to-service interval on subsequent reproductive performance, including litter size, has been reported. This discrepancy could be due to different lactation length among studies. In the present study gilts/sows were weaned at $21 \mathrm{~d}$ after farrowing and uterine involution may not be complete in sows weaned at this time. Thus, sows weaned at $21 \mathrm{~d}$ or less are more likely to have a reduction in litter size at the subsequent farrowing (Koketsu and Dial 1998). In fact, each day increase in the farrowing to conception interval (less than $36 \mathrm{~d}$ ) leads to an increase in number of live pigs per litter up to 0.09 pigs (Clark and Leman 1987).

The mean number of stillborn pigs per litter in the present study was below the 3-8\% of all pigs born in highly prolific sows (commercial lines derived from Large White x Landrance) (Borges et al 2005, Vanderhaeghe et al 2010). The highest number of stillborn pigs per litter occurred in spring and winter, which indicates that thermal stress was not associated with this reproductive problem. Stillbirths in pigs is a multifactorial problem where litter size, parity, sow's body condition and farrowing supervision/ birth assistance seems to be the most relevant risk factors associated with stillborn piglets (Vanderhaeghe et al 2013). In the present study, the correlation coefficient between total pigs born and stillborn piglets was $r=0.35$, therefore, litter size was mildly related to this reproductive problem.

The average number of mummies per litter in the present study was well above the $<0.2 \%$ considered normal for commercial pig farms (Christianson 1992). Probably the number of mummies found in the present study reflected clinical signs associated with an infectious agent. The highest percentage of mummies were observed in both summer and winter. Thus, it seems that other factors aside climate were responsible for the occurrence of mummies. The significant correlation between total pigs born and mummies observed in this study $(\mathrm{r}=0.37)$ suggests that overcrowding of the uterus with a fixed capacity, space per foetus was reduced, leading to the death and subsequent mummification of some foetuses due to insufficient area for foetal development.

It can be concluded that in this zone of low-temperature fluctuations throughout the year, several components of the reproductive function are susceptible to summer heat stress in commercial crossbred gilts and sows. These include PR, FR, repeat breeding and number of live pigs per litter. The occurrence of dead and mummified pigs at birth was affected by factors other than climate variation. Additionally, PCAI with $3 \times 10^{9}$ sperm cells does not improve the reproductive performance of gilts/sows when using CAI, although 0.2 piglets born alive per litter is expected in gilts/sows inseminated with the CAI method as compared with the PCAI. Thus, in this particular zone sows and gilts need to be cooled as efficiently as possible during the summer in order to increase fertility.

\section{REFERENCES}

Almond PK, Bilkei G. 2005. Seasonal infertility in large pig production units in an Eastern-European climate. Aust Vet J 83, 344-346.

Auvigne V, Leneveu P, Jehannin C, Peltoniemi O, Salle E. 2010. Seasonal infertility in sows, a five-year field study to analyze the relative roles of heat stress and photoperiod. Theriogenology 74, 60-66.

Bertoldo M, Grupen CG, Thomson PC, Evans G, Holyoake PK. 2009. Identification of sow-specific risk factors for late pregnancy loss during the seasonal infertility period in pigs. Theriogenology 72, 393-400.

Bertoldo MJ, Holyoake PK, Evans G, Grupen CG. 2012. Seasonal variation in the ovarian function of sows. Reprod Fertil Dev 24, 822-834.

Bloemhof S, van der Waaij EH, Merks JWM, Knol EF. 2008. Sow line differences in heat stress tolerance expressed in reproductive performance traits. J Anim Sci 86, 3330-3337.

Borges V, Bernardi M, Bortolozzo F, Wentz I. 2005. Risk factors for stillbirth and foetal mummification in four Brazilian swine herds. Prev Vet Med 70, 165-176.

Britt JH, Szarek VE, Levis DG. 1983. Characterization of summer infertility of sows in large confinement units. Theriogenology 20, 133-140.

Christianson WT. 1992. Stillbirths, mummies, abortions, and early embryonic death. Vet Clin North Am Food Anim Pract 8, 623-639.

Clark LK, Leman AD. 1987. Factors that influence litter size in swine, parity 3 through 7 females. J Am Vet Med Assoc 191, 49-58.

Dewey CE, Marti SW, Friendship RM, Kennedy BW, Wilson MR. 1995. Associations between litter size and specific sow-level management factors in Ontario swine. Prev Vet Med 23, 101-110.

Distl O. 2007. Mechanisms of regulation of litter size in pigs on the genome level. Reprod Domest Anim 42, 10-16.

Egbunike GN, Steinbac J. 1980. Seasonal changes in sow fertility in a humid tropical environment. Zbl Vet Med A 27, 109-117.

Fontana DL, Ulguim RR, Sbardella PE, Bernardi ML, Wentz I, et al. 2014. Fixed-time post-cervical artificial insemination in sows receiving porcine luteinizing hormone at oestrus onset. Anim Reprod Sci 144, 109-114.

Gourdine JL, Quesnel H, Bidanel JP, Renaudeau D. 2006. Effect of season, parity and lactation on reproductive performance of sows in a tropical humid climate. Asian-Aust J Anim Sci 19, 1111-1119.

Hemsworth PH, Barnett JL. 1990. Behavioural responses affecting gilt and sow reproduction. J Reprod Fertil Suppl 40, 343-354.

Holtkamp DJ, Kliebenstein JB, Neumann EJ, Zimmerman JJ, Rotto $\mathrm{HF}$, et al. 2013. Assessment of the economic impact of porcine reproductive and respiratory syndrome virus on United States pork producers. J Swine Health Prod 21, 72-84.

Hurtgen JP, Leman AD. 1980. Seasonal influence on the fertility of sows and gilts. J Am Vet Med Assoc 177, 631-635.

Iida R, Koketsu Y. 2013. Interactions between climatic and production factors on returns of female pigs to service during summer in Japanese commercial breeding herds. Theriogenology 80, 487-493.

Iida, R, Koketsu, Y. 2016. Lower farrowing rate in female pigs associated with higher outdoor temperatures in humid subtropical and continental climate zones in Japan. Anim Reprod 13, 63-68. 
Isom SC, Prather RS, Rucker EB. 2007. Heat stress-induced apoptosis in porcine in vitro fertilized and parthenogenetic preimplantation-stage embryos. Mol Reprod Dev 74, 574-581.

Janse van Rensburg L, Spencer BT. 2014. The influence of environmental temperatures on farrowing rates and litter sizes in South African pig breeding units. Onderstepoort J Vet Res 81, 1-7.

Johnson JS, Sanz Fernández MV, Patience JF, Ross JW, Gabler NK, et al. 2015. Effects of in utero heat stress on postnatal body composition in pigs: II. Finishing pigs. J Anim Sci 93, 82-92.

Koketsu Y, Dial GD. 1998. Interactions between the associations of parity, lactation length and weaning to conception interval with subsequent litter size in swine herds using early weaning. Prev Vet Med 37, 113-120.

Kornegay ET, Thomas HR. 1983. Effects of air-conditioned versus naturally ventilated housing during hot weather on the reproductive efficiency of gilts and sows. Livest Prod Sci 10, 387-395.

Le Cozler Y, Dagorn J, Dourmad JY, Johansen S, Aumaitre A. 1997. Effect of weaning-to-conception interval and lactation length on subsequent litter size in sows. Livest Prod Sci 51, 1-11.

Liao CW, Veum TL. 1994. Effects of dietary energy intake by gilts and heat stress from days 3 to 24 or 30 after mating on embryo survival and nitrogen and energy balance. J Anim Sci 72, 2369-2377.

Lopes TP, Sánchez-Osorio J, Bolarin A, Martínez EA, Roca J. 2014. Relevance of ovarian follicular development to the seasonal impairment of fertility in weaned sows. Vet J 199, 382-386.

Love RJ, Evans G, Klupiec C. 1993. Seasonal effects on fertility in gilts and sows. J Reprod Fertil 48, 191-206.

Mazzoni C, Tonon F, Borri E, Raffi V, Scollo A, et al. 2014. Distribution of regular and irregular inter-oestrus interval in sows during different months of the year in Northern Italy. Large Anim Rev 20, 255-257.

Muns R, Malmkvist J, Larsen MLV, Sørensen D, Pedersen LJ. 2016. High environmental temperature around farrowing induced heat stress in crated sows. J Anim Sci 94, 377-384.

NRC, National Research Council. 2012. Nutrient requirements of swine. $11^{\text {th }}$ ed. National Academy Press, Washington, DC, USA.

Nteeba J, Sanz-Fernández MV, Rhoads RP, Baumgard LH, Ross JW, et al. 2015. Heat stress alters ovarian insulin-mediated phosphatidylinositol-3 kinase and steroidogenic signaling in gilt ovaries. Biol Reprod 92, 148-156.

Olanratmanee EO, Thanawongnuwech R, Kunavongkrit A, Tummaruk P. 2014. Reproductive performance of sows with and without PRRS modified live virus vaccination in PRRS-virus-seropositive herds. Trop Anim Health Prod 46, 1001-1007.

Peltoniemi OA, Love RJ, Heinonen M, Tuovinen Saloniemi H. 1999. Seasonal and management effects on fertility of the sow, a descriptive study. Anim Reprod Sci 55, 47-61.

Peters AR, Pitt RL. 2003. Seasonal infertility in pigs in the east of England. Pig J 52, 13-27.

Prunier A, Messias de Braganca M, Le Dividich L. 1997. Influence of high ambient temperature on performance of reproductive sows. Livest Prod Sci 52, 123-133.
Sbardella PE, Ulguim RR, Fontana DL, Ferrari CV, Bernardi ML, et al. 2014. The post-cervical insemination does not impair the reproductive performance of primiparous sows. Reprod Domest Anim. 49, 59-64.

Serret CG, Alvarenga MVF, Coria ALP, Corcini CD, Correa MN, et al. 2005. Intrauterine artificial insemination of swine with different sperm concentrations, parities, and methods for prediction of ovulation. Anim Reprod 2, 250-256.

Suriyasomboon A, Lundeheim N, Kunavongkrit A, Einarsson S. 2006. Effect of temperature and humidity on reproductive performance of crossbred sows in Thailand. Theriogenology 65, 606-628.

Thom EC. 1959. The discomfort index. Weatherwise 12, 57-61.

Tompkins EC, Heidenreich CJ, Stob M. 1967. Effect of post-breeding thermal stress on embyronic mortality in swine. JAnim Sci 26, 377-380.

Tummaruk P, Lundeheim N, Einarsson S, Dalin AM. 2000ª . Reproductive performance of purebred Swedish landrace and Swedish Yorkshire sows, I. Seasonal variation and parity influence. Acta Agric Scand Sect A Anim Sci 50, 205-216.

Tummaruk P, Lundeheim N, Einarsson S, Dalin AM. 2000 ${ }^{\mathrm{b}}$. Reproductive performance of purebred Swedish Landrace and Swedish Yorkshire sows, 11. Effect of mating type, weaning to first service interval and lactation length. Acta Agric Scand Sect A Anim Sci 50, 217-224.

Tummaruk P, Tantasuparuk W, Techakumphuk M, Kunavongkrit A. 2004. Effect of season and outdoor climate on litter size at birth in purebred Landrace and Yorkshire sows in Thailand. $J$ Vet Med Sci 66, 477-482.

Vanderhaeghe C, Dewulf J, Ribbens S, de Kruif A, Maes D. 2010. A Cross-sectional study to collect risk factors associated with stillbirths in pig herds. Anim Reprod Sci 118, 62-68.

Vanderhaeghe C, Dewulf J, de Kruif A, Maes D. 2013. Non-infectious factors associated with stillbirth in pigs, A review. Anim Reprod Sci 139, 76-88.

Watson PF, Behan JR. 2002. Intrauterine insemination of sows with reduced sperm numbers, results of a commercially based field trial. Theriogenology 57, 1683-1693.

Wettemann RP, Bazer FW, Thatcher WW, Caton D, Roberts RM. 1988. Conceptus development, uterine response, blood gases and endocrine function of gilts exposed to increased ambient temperature during early pregnancy. Theriogenology 30, 57-74.

Williams AM, Safranski TJ, Spiers DE, Eichen PA, Coate EA, Lucy MC. 2013. Effects of a controlled heat stress during late gestation, lactation, and after weaning on thermoregulation, metabolism, and reproduction of primiparous sows. J Anim Sci 91, 2700-2714.

Wu G, Bazer FW, Wallace JM, Spencer TE. 2006. Intrauterine growth retardation. Implications for the animal sciences. J Anim Sci 84, 2316-2337.

Young B, Dewey C, Friendship R. 2010. Management factors associated with farrowing rate in commercial sow herds in Ontario. Can Vet $J$ 51, 185-189.

Zhao Y, Flowers WL, Saraiva A, Yeum K-J, Kim SW. 2011. Effect of heat stress on oxidative stress status and reproductive performance of sows. J Anim Sci 89, 108. 